\title{
The Possibility of Semantic Features and Analysis of Figures of Speech Cognitive Figures and Expressive Figures
}

\author{
Liu Dawei $^{*} \quad$ Wang Zhiguang ${ }^{* *}$
}

\begin{abstract}
In this paper, linguistic methodology is suggested for approaching figures of speech formed due to shift of cognitive relations. First, requisite features, possible features and impossible features are proposed on the basis of semantic analysis and their interrelationships and expressions are discussed. Then it is further argued that all figures formed due to shift of cognitive relation are expressed to accept an impossible feature; and there are four semantic forms to accept it: "zero distance/distanced", "implicit/explicit", "direct/indirect", "positive/negative". Finally, starting from the two approaches to figures we comment on the traditional idea of separating decoration and substance and the new idea of "function as form".
\end{abstract}

Key words: figures of speech, requisite features, possible features, impossible features, cognitive, expressive

\section{Introduction}

Traditional rhetoric approach to figures remains at the stage of data collection and various language constructions with special expressive values are kept in a treasure box, something before serious research-having not formed a viewpoint theoretically sound enough to encompass these chaotic materials in a unified framework or a unique methodology. It is hard for rhetoric to go beyond the horizon of common sense without such theory and methodology.

We have noticed that the use of some figures not only cause shift of meaning, but also lead to the changes in our cognitive relation to things, on which their rhetorical values are based. Such figures include comparison, including simile, metaphor and metonymy,

\footnotetext{
${ }^{*}$ Liu Dawei: Department of Chinese Language and Literature, Fudan University, Shanghai 200062, China. E-mail: liudawei3000@sina.com.

** Wang Zhiguang: School of Foreign Languages, Zhejiang University, Hangzhou 310058, Zhejiang, China.wzhiguag@mail.hz.zj.cn.
} 
analogy, antonomasia/synecdoche, transferred epithet, zeugma, and hyperbole, plus facts related to symbolism and empathy. They are different from other figures and form a separate category. We hereby informally call them cognitive figures.

It is to be emphasized that we will not be constrained by these traditional figures; instead, we only use these data found in facts denoted by these names as an easy basis for discussions due to people's familiarity with the traditional rhetoric. There are indeed some valuable and in-depth researches into one or more of cognitive figures, but unfortunately they are outside linguistics. These achievements can be utilized, but as a branch of linguistics, rhetoric needs its own paradigms, without which, to tell the truth, the discipline as a whole has been hopelessly exhausted against the background of modern scientific development. It is our grand objective to attempt at the paradigms of rhetoric via the study of cognitive figures.

\section{Requisite features, possible features and impossible features}

The shift of meaning caused by the use of cognitive figures is ultimately reflected in the change of meaning of a particular word. So we are led to think about this question: how can we explicitly describe in linguistic terms the shift of word meaning after the use of figures?

Semantic features analysis, or sememic analysis, divides word meaning into a group of distinctive features. In this method, word meaning is not regarded as a reflection of the property of its referent, but its minimum distinction from other referents, as represented by a group of distinctive features. Any referent can be distinguished from others as long as it has a whole group of such features and its linguistic expression can be referred to by a word. If a word refers to a referent as a set of features, then the sole criterion to enter this set is to have this group of features as a requisite whole. For instance, the word 'cup' can be used to refer to various concrete referents, which comprise a set of cups, anyone of which must have the following distinctive features:

/cup/: [+material, +concrete, +inanimate, +solid, +container, +cylinder, +holding liquid, +drinking utensil]

The first three are categorical features, which depends on the lexical category or subcategory of the word. Here +material, +concrete, +inanimate is related with the nominal category; the latter five features are experiential and dependent on its lexical meaning.

However, this analysis can only deal with the semantic components of a word, but cannot show its shift of meaning. If a set of distinctive features only show the connotative features, the requisite features of the referent of a word, there should be denotative features-unique features beyond this common criterion for the minimum requisite connotative features for each referent within the set of referents (denotation). These features are exemplified by a cup "with a lid", or a cup "with a handle"; a "porcelain" cup, 


\section{Liu Dawei $\quad$ Wang Zhiguang}

or a "plastic" cup; a cup with a "broken rim" or a cup "covered by tea stain"; a cup "used by Empress Dowager Cixi" or a cup "made in the year of Emperor Qianlong"...A set of requisite connotative features only constitute an abstract cup. To form a concrete cup that we observe, we must add an infinite number of denotative features.

Anything that is called a cup must show those requisite connotative features, but we cannot predict the denotative features of any cup. Connotative features are required whereas denotative features are possible. Hence the terms requisite features and possible features. The former is interchangeable with distinctive features or connotative features, and the latter with denotative features. All these features are semantic when used in meaning analysis and cognitive when used in cognition of things.

It is impossible to predict the particular possible features of a word, which, however, fall within a scope; features outside the scope are impossible features. For instance, it is impossible to attribute features like "yelling", "sprouting" or "containing three bookcases" to a "cup". So we have an additional term: impossible features.

We will focus on impossible features here and further analysis is needed. First, it can be classified into two varieties:

A. Qualitatively impossible features. +inanimate is a requisite feature of a "cup", for it is a material entity without life. But "yelling" and "sprouting" is based on life. Semantic incompatibility decides these two qualitative impossible features for a "cup".

B. Quantitatively impossible features. A "cup" is a container usually for liquid, and possibly for solid objects. "Bookcases" are solid and qualitatively possible to be put in a cup, but you cannot possibly find such a large cup. So "containing three bookcases" is a quantitatively impossible feature of a "cup".

Thus, a quantitatively impossible feature is based on two prerequisites: it must be a qualitative possible feature to make it necessary to discuss the quantitative possibility; a quantitative expansion or contraction has to cause cognitive change. So it is not an impossibility in an particular environment but a factual impossibility. Here we propose two criteria to identify:

A. If a quantitative feature is true, there will be a change in the degree of normal cognitive relation between different things. This will change our cognitive vision of the world and make this a quantitatively impossible feature. For example, "very long" is a qualitatively possible feature of "white hair" and "three thousand yards" is within the "scope" of "very long". But when we accept "three thousand yards of white hair" and try to imagine it, we must adjust our normal cognition of "white hair" and its proportion to the human body or even rivers and mountains, creating a grotesque image. In this situation, "three thousand yards" becomes a quantitatively impossible feature for "white hair". 
Similarly, we must discard our normal cognition to imagine ourselves facing a huge cup containing 3 bookcases and snowflakes as large as "bed mats" flying. But it is something different to say:

(1) Měi fênzhōng, dōu yǒu shí jiā y̌̌ngyuàn tóngshí sànchăng, jiēdào shàng dōu shì zháole huǒ de rén. (每分钟,都有十家影院同时散场,街道上都是着了火的人。—黄亚洲:《黄浦江》。/ Every minute, there are ten theaters emptying and people on the street seem to be caught in fire.

- Huang Yazhou, Huangpu River)

(2) Tā gănmíngr dă ge pènti yě děi shìxiān qǐngshì lǐngdăo.(她......赶明儿打个喷喷也得事先请示 领导。——王蒙:《湖光》/ She may have to apply to the leader before sneezing some day. ——Wang Meng, Lake Light)

"Every minute, there are ten theaters emptying" seems to be a quantitatively impossible feature in frequency, but we need not change its proportion to the frequency of other things to imagine the image if this actually happened. And we do not need to discard normal cognition of frequency to imagine how "to apply to the leader before sneezing", so they do not affect the cognitive relation.

B. If a quantitative feature is true, there will be an elimination of difference between things. This will change our cognitive vision of the world and make this a quantitatively impossible feature. For example, humans and lions can both "run frantically" and "jump madly", but lions show a drastic degree of "madness" far exceeding human capability. If we imagine a man "runs frantically" and "jumps madly" as a lion, the difference between man and animal disappears:

(3) Wǒ xiàng fāqíngde xióng shīzi yíyàng zài níngjìngde dàjiē shang yìbiān fêngpāo,yibiān kuáng tiào.(我像发情的雄狮子一样在宁静的大街上一边疯跑, 一边狂跳。(刘毅然《摇滚青年》) / I ran frantically and jumped madly in the quiet street like a lion in heat.)

The possible feature of a lion is a quantitatively impossible feature of a man. Imposing such a feature on a man will change our cognition of this man. To put it simply, we will think this guy abnormal and grotesque. Compare:

(4) Jīntiānde yuèliang hé jīntiānde tāiyang yíyàng yuán.(今天的月亮和今天的太阳一样圆。/ The moon today is as round as the sun today.)

The moon and the sun can share the feature of 'roundness' without even difference in degree, so the idea of these two being 'as round' will not change our cognition of the moon. The feature of 'roundness' is a quantitatively possible feature for both. There is a method to discriminate the two situations, by checking their reversibility: "The moon today is as round as the sun today" is equivalent to "The sun today is as round as the moon today".But we can not say: "The lion in heat ran frantically and jumped madly as a man ('I')."

\section{The relationship between the three features}




\section{Liu Dawei Wang Zhiguang}

There is a definite amount of requisite features to a word, which are exhaustible as the minimum for distinguishing it from other words, distinguishing its referent from other referents. By feature analysis, we get a limited set of its distinctive semantic features, for example, the eight features for a 'cup' mentioned above. Of course, there may be discrepancies in analyzing the requisite features to a word, due to different operational methods, but we can achieve theoretical agreement. Since the number of requisite features to a word is definite, the addition, subtraction or change of these will lead to different words. "+glass" may be a possible feature of a "cup", but the addition of it as a requisite feature will make the word a "glass"; in ancient Chinese, subtraction of the requisite feature "+white hooves" to word "shū (输)" makes the pony a horse.

But there is an indefinite amount of possible features to a word, which are inexhaustible. We have new knowledge of a referent all the time, and add more and more new possible features accordingly. We can always control its scope despite of the multiplication of features, for possible features must be compatible with requisite features, on which they are based. Both "+porcelain" and "+plastic" as possible features are solid, compatible with the requisite features +solid. "with a broken rim" happens to the wall of a receptacle, which is a requisite feature of a "cup"... Thus we can define possible features with requisite features to a word-

Any feature not contradictory with requisite features to a word is its possible feature.

The requisite features actually define an infinite set of possible features, unless they are incompatible with requisite features.

It is easy to imagine much more impossible features than possible features. They are all the remaining features when we subtract requisite and possible features. But there are qualitatively and quantitatively impossible features, so it is difficult to define its semantic scope.

First, we could define qualitatively impossible features with requisite features-

Any feature contradictory with requisite features to a word is its qualitatively impossible feature.

As we said before, "yelling" and "sprouting" is contradictory with +inanimate as a requisite feature of a "cup", so it is a qualitatively impossible feature. Therefore, qualitatively impossible features are also an infinite set defined by the requisite features, though contrary to the definition of possible features.

As we said before, there are quantitatively possible features only when qualitatively possible features exist. And qualitative possibility satisfies the need of requisite features. So quantitatively impossible features or the scope of its set cannot be defined by requisite features. But there are quantitative limits to the requisite features to a word, with the upper and lower limits defining the maximum and minimum quantity of the set of features. Its 
core realizes quantitatively the typical features of the referent. If one fancifully built a cup as high as a building, we had to admit it as a cup. But it is almost impossible, thus a quantitatively impossible feature. Quantitative limits are not a strict definition of quantitatively impossible features. They are only a general scope for actual quantitative possibility, and also for quantitative impossibility.

All in all, possible features depend on the quality of requisite features, qualitatively impossible features reversely depend on the requisite features, while quantitatively impossible features depend on the quantitative limits.

\section{Within a word and without: the ways of existence for semantic features}

The ideal feature analysis would yield a limited amount of semantic features, which are minimum and no longer possible to further analyze. Thus we could exhaust the meaning of the whole vocabulary of a language. To avoid semantic self-circulation, we need to substitute a new metalanguage for natural language words. But there are insurmountable technical barriers, so no one has designed such a thing. We should not wait till it is possible, and so have to make do with the existing vocabulary. But this method of using natural words to denote semantic features will result in the elimination of the requirement for "minimum" features. Thus, we have "+solid", "+container" as features (though not minimum either), as well as "+used by Empress Dowager Cixi" and "+yelling". Though they are not true semantic features, but they greatly facilitate the analysis.

Another result is, there are two ways of existence for semantic features. One existence is within a word, as requisite features. We cannot see them directly - in "I bought a cup", we only see a word "cup". Only by semantic analysis can we realize the various features inherent in it, as mentioned above.

Another way of existence is outside the word, in the form of its semantic predicate. Any collocated phrases of the word represent some of its semantic features as its semantic predicate:

(5) quēle yí gè kǒu de bēizi (缺了一个口的杯子 / a cup with a broken rim)

(6) Bēizi quēle yí gè kǒu (杯子缺了一个口 / a cup is broken at the rim)

(5) and (6) are different syntactically, but equivalent semantically in a semantic representation. Even-

(7) Xiăo māo dāfān le bēizi.(小猫打翻了杯子。/ The cat tipped over a cup.)

is a semantic representation, meaning a "cup" was "tipped over". Reversely, the "cat" also features "tipped over the cup".

The features existing outside a word as semantic predicate are all possible features. If requisite features surfaced to predicate, there would be tautology:

(8) Āyí shì nŭde.(阿姨是女的。/ An aunt is female.) 


\section{Liu Dawei $\quad$ Wang Zhiguang}

(9) Bēizi shì róngqì. (杯子是容器。/ A cup is a container.)

"+female" as a requisite feature of "aunt" is self-evident if we understand the latter, so if we represented it, it would be tautology, unless we were not understood. It is the same with "+container" and "cup".

Impossible features will, of course, never appear within or without a word. An originally impossible feature may predicate a word when its set of requisite features or quantitative limits are changed to make it possible:

(10) Chánchánde tóufa liúbiàn quánshēn. (粽渌的头发流遍全身(江河《向日葵之一》)/ Babbling

hair soaked the whole body)

"babbling" and "soaked the whole body" was impossible features of "hair", but collocation with the word as predicative and predicate makes them possible. The prerequisite for this change is that its requisite feature "+solid" has been replaced by "+liquid".

\section{Cognitive figures: the pursuit of impossible features}

The choice of possible features instead of impossible features is in fact the normal usage of a word. Once it is used in a cognitive figure of speech, the norm is upset, as typified by the acceptance of impossible features as possible features. This is symbolized by their collocation with the word in semantic representation. The fashion of acceptance can be analyzed from various angles. But before that, we need to establish the four concepts of substance, medium, substance word and medium word. Substance seeking impossible features depends on something in between: medium. The basis of simile is a medium, but our medium is not limited to that. The words representing substance and medium are substance words and medium words respectively.

\subsection{Zero-distance / distanced acceptance}

"Distance" means semantic distance. If a word representing an impossible feature can be directly collocated with the substance word without any syntactic barriers, the distance is zero. But in more cases, the substance word is separated from the word for an impossible feature by medium words, words meaning resemblance or identity, and words meaning uncertainty, like "haoxiang (好像), sihu (似乎), fangfu (仿佛)"(seem like), so there is increased semantic distance. And distance may be long or short:

(11) Tàiyang wōniú shìde páguò zhăichángde tiānkōng. Yǒngyuănde lán píngzi yíyàng de tiānkōng, xībóde niúnăi yíyàng de tiānkōng. (太阳蜗牛似的爬过窄长的天空。永远的蓝瓶子一样的天空, 稀 薄的牛奶一样的天空。(蔡测海《往前往后》) / The sun crawled across the sky like a snail, always as blue as blue bottle, as thin as milk. )

Simile is used here. The purpose is to impose "crawl" on the sun, though by the medium of medium word "snail" and “似的”. Their semantic relationship is remote because of these barriers. In metaphor- 
The Possibility of Semantic Features and Analysis of Figures of Speech C-Cognitive Figures and Expressive Figures

(12) Rìzi jiù shì sōnghuādàn, lǐ xiāng wài bú chòu. (日子就是松花蛋,里香外不臭。(王愈奇《河上的

诱惑》) / ... days are ancient eggs, fragrant both inside and out.)

Though there is the barrier of "ancient eggs", the copula "are" puts the impossible feature closer to "days".

(13) (Gǒuqǐtóu fàng zài yí gè yuánbăo lán lǐ,)......Gǒuqưtóu dàizhe yǔshuǐ, nŭháizi de shēngyīn yě dàizhe yǔshuǐ. ((枸杞头放在一个元宝篮里)......枸杞头带着雨水, 女孩子的声音也带着雨水。(汪 曾祺《故乡的野菜》) / (wolfberries dripping with rainwater, and the girl's voice also dripping with rainwater)

"dripping with rainwater" is an impossible feature for "the girl's voice", but syntactically it seems to have been directly predicative. A closer analysis shows the indispensable medium word "wolfberries", though in extraposition. This is the usage of zeugma. But here the semantic distance is smaller than in simile or metaphor.

(14) (Zài shāngǔ shēnchù).......Liăng tiáo niánqīngde xiăojìng dănqiède jiēwěn. (在山谷深处, 两条

年轻的小径胆怯地接吻(李钢《在山上》)/Young paths timidly kissed)

(15) Yángguāng zhèngzài nà gè tiānkōng lǐ piāoyáng. tiányě zài qínglăngde pūzhăn kāilái.(阳光正在

那个天空里飘扬,田野在晴朗地铺展开来。(孙文昌(夏季台风》) / The sun was fluttering in that sky.

The fields in a sunny way spread...)

In (14), "young" and "kissed" are impossible features for "path", but possible in personification. In (15), impossible features "fluttering" for "sun" or "sunny" for "fields" are used because of transferred epithet. On the surface, analogy, transferred epithet and empathy would admit impossible features without barriers, but there are implicit media in analogy and transferred epithet to keep a certain semantic distance. Only empathy and hyperbole bring no media; impossible features bear no distance to substance words:

(16) Língdāng shìde qīngcuìde xiăngshēng jīnguāng sìjiàn. (铃铛似的清脆的响声金光四溅。(江河

《息壤》) / like a bell clear tingling emitting golden shine)

Visual "emitting golden shine" is collocated with audio "clear tingling" without a medium. If we add words like "hăoxiàng(好像), făngfú(仿佛)" (seem like) to show uncertainty, there will be some semantic distance:

(17) Tàiyang gāng yì chūlai, dìshang y̌jīing xiàng xiàle huǒ. (太阳刚一出来, 地上已经像下了火。

(老舍《骆驼祥子》) / When the sun rises, it seems to have rained fire on the ground.)

In this case of hyperbole, "xiang (像 / like)" mediates the impossible feature "have rained fire" and "on the ground".

\subsection{Implicit / explicit acceptance}

Impossible features to be accepted can be realized as words:

For example, "burning his rear" in Ex 18:

(18) Nüháizi de hănshēng xiàng huǒmiáo yíyàng shāozháo tāde pìgu, tā gèng kuài de wăng shàng pá. (女孩子的喊声像火苗一样烧着他的屁股,他更快地往上爬。(莫言(枯河》)/ The girl's screaming 


\section{Liu Dawei Wang Zhiguang}

seemed some fire burning his rear, making him climbing faster.)

And often they are implicit:

(19) Gēshēng xiàng yì zhī guàzhe báisè fān de xiăo chuán, wǒde xīn jiànjiàn qūyú níngjìng. (歌声像

一只挂着白色帆的小船, 我的心渐渐趋于宁静。(于坚《蛐蛐儿的年代》) / The song was like a boat

with white sail, and my mind became tranquil.)

In (19), there is no mention of any impossible features to be accepted, but anyone trying to comprehend this sentence will be tempted by "xiàng (像 / like)" to find something to relate with "gēshēng (歌声 / song)" among the various possible features of "guàzhe báisè fān de xiăo chuán (挂着白色帆的小船)". Since the "song” and “a boat with white sail” are distanced semantically, so the possible features of the former are mostly impossible features of the latter, so we assume an implicit impossible feature here.

\subsection{Direct / indirect acceptance}

How can impossible features be attached to a word? There are roughly two ways: indirect or with medium, by the semantic relationship between words which obtains between substance word A and medium word B in a context, and transfers the possible features of B (impossible features of A) onto A. Such semantic relationship contains resemblance, spatial-temperal closeness or comprising:

(20) Tāde liănsè làhuáng fànqīng, xiàng yì tiáo yānguò de suān huánggua. (她的脸色蜡黄泛青, 像

一条腌过的酸黄瓜。(北村《构思》)/ Her pallid face was like a pickled cucumber.)

(21) Yì zhī lán húdié zhèng tíngbó zài tā nà tóufà liúchéng de xiăo xī lǐ. (一只蓝蝴蝶正停泊在她那

头发流成的小溪里。(维维《街》)/ A blue butterfly was moored on her stream of hair.)

Obviously, the impossible features here are accepted by word A because of the resemblance between substance and medium. The resemblance in (20) is more obvious (face-pickled cucumber) than in (21), where we must find "boat" implicit in the main clause and "flow" implicit in the object, to substantiate the resemblance between "blue butterfly" and "hair".

(22) Xiăo jiàochē tòngde zuǒyòu luàn huàng.(小轿车痛得左右乱晃。(吴滨《写给男人看的故事》) /

The car was so painful that it shook from side to side.)

Because of the close space between "car" and "I" the driver, "so painful that it shook from side to side" was said of the "car".

The other way is direct or medium-less, as in empathy and hyperbole, based on our psychological reality.

\subsection{Positive / negative acceptance}

If we take the acceptance by substance words of their impossible features (or the possible features of medium words) as positive acceptance, then the acceptance by medium words of impossible features (or the possible features of substance words) is negative. The above examples are all cases of positive acceptance. We have noted that the resemblance and closeness between substance words and medium words will increase, resulting in the 
substitution of medium words for substance words. The cause of such semantic substitution will be discussed elsewhere. But we want to note that after the substitution the substance words disappear from discourse, thus eliminating the acceptance of their impossible features. On the other hand, substitution means that the medium words play the role of substance words in the original context, whose semantic features are of course possible for substance words but impossible for medium words. So substitution must reverse the direction of accepting impossible features:

(23) Tā tízhe tóngluó, tā tízhe yí gè tàiyang. Shǒuzhōng de tàiyang chéndiāndiānde. Tā yòng xiàngmù luóchuí qiāojī tàiyang. (他提着铜锣, 他提着一个太阳。手中的太阳沉甸甸的。他用橡木锣 槌敲击太阳。(少鸿(黑松林》) / ( He had a gong in hand. He had a sun in hand, which was heavy. He struck the sun with an oak hammer.)

(24) Hēi sīróng qípáo yíngmiàn guòlai. (黑丝线旗袍迎面过来。(李晓《关于行规的闲话》) / The dark velvet gown came up.)

Strong resemblance allows the "sun" to replace the "gong", so that the medium word appears in the context of "gong", accepting negatively the whole context—-in hand", "heavy" and "struck with an oak hammer"-- as impossible features. Similarly, strong closeness also causes the "dark velvet gown" to negatively accept the impossible feature "came up".

The direction of a particular acceptance in discourse depends on our judgment whether the related word is a substance or a medium. If "car" in (22) is considered as a medium rather than a substance, the acceptance of "so painful that it shook from side to side" is negative; if "dark velvet gown" in (24) is considered as a substance word, the acceptance of "come up" is positive.

On the other hand, we can observe the acceptance from the type of impossible features accepted:

4.5. The acceptance of qualitatively / quantitatively impossible features

The above examples are basically qualitatively impossible features. Here are some examples of quantitatively impossible features:

(25) Nürén rúguǒ huì hē jiǔ néng xiàng chōushuǐ mătǒng shìde huāhuāde guàn. (女人如果会喝酒能 像抽水马桶似的哗哗地灌。(刘毅然(摇滚青年》) / Ladies who drink can flush alcohol down like a toilet.)

(26) Băiyóu lù shàihuà le, shènzhìyú pùhù ménqián de tóngpái hăoxiàng yě yào shàihuà. (柏油路晒 化了, 甚至于铺户门前的铜牌好像也要晒化。(老舍《骆驼祥子》)/ Asphalt roads melted, and even the copper tablet before the shop seems to be melting.)

In (25), a "lady" can "drink" like a "toilet", though cannot bear "flushing" to such a degree, hence quantitatively impossible. In (26), it is quantitatively impossible for the sun to "melt the copper tablet", but with "hăoxiàng (好像)" as a barrier, the degree of 


\section{Liu Dawei Wang Zhiguang}

"melting" is reduced as the impossible feature is indirectly accepted.

We are more concerned with the necessary semantic changes after these words accept impossible features. As we noted, qualitatively impossible features of a word depend on its requisite features; while its quantitatively impossible features depend on its quantitative scope. From this we can infer that an impossible feature, if turned possible, will surely change the requisite features or quantitative scope of the word. For qualitatively impossible features, if "steam" can accept "touched the jute leaves" as possible features, the "+gas" among its requisite features must be replaced by "solid"; for quantitatively impossible features, if the "sun" can "melt the copper tablet", then its upper limit of scope must have been expanded. To comprehend these figures of speech linguistically, we must realize that their use entails changes in the set of features for the words by the imposition of impossible features.

\section{Cognitive figures and expressive figures}

From the above, we see that the common function of these cognitive figures of speech is to impose originally impossible features on words. If there is no acceptance of impossible features, we are not dealing with cognitive figures, even if with the same language form:

(27)Zhè zhī bēizi xiàng huāpíng yíyàng yòu xì yòu cháng. (这只杯子像花瓶一样又细又长。/ The cup is as thin and long as a vase.)

(28)Zhè zhī bēizi xiàng yì zhī huāpíng. (这只杯子像一只花瓶。/ The cup is like a vase.)

In (27), "thin and long" are not impossible features of a "cup", so the function of the figure is a vivid and exact comparison rather than a cognitive simile, though similar in form. In (28) we are not shown the particular connection between the "cup" and "vase", but it is hard to imagine which possible feature of the latter is an impossible feature of the former, so (28) is not a real simile.

Once we set impossible features as a criterion for identifying cognitive figures, we find that there are two totally different types of figures in traditionally rhetoric. One type, which we call expressive figures, is aimed at enhancing expressiveness-more exact, vivid, emphatic, concise, but not subject to cognitive changes. These figures include word imitation, parallelism, antithesis, and head-on. Another type represents special experiences, the changes in cognitive relationship with the objective world, though this is not clarified in traditional rhetoric. These cognitive figures include comparison, transferred epithet, zeugma and phenomena like symbolism and empathy. While the former type is a variant in form, the latter is a variant in content. But we have a mixed format in some traditional figures like simile, hyperbole and metonymy:

(29) Chénjìde wǔhòu, yángguāng kăorě le zhěnggè hé'àn, yuănchù de cūnzhuāng, yuănchù nàxiē dī’ăi mijí de fángzi fāchū làotiě bān wēi hóng de yánsè. (沉寂的午后, 阳光烤热了整个河岸,远处的 
The Possibility of Semantic Features and Analysis of Figures of Speech C-Cognitive Figures and Expressive Figures

村庄,远处那些低矮密集的房子发出烙铁般微红的颜色。(苏童《棉花地稻草人》) / The afternoon sun baked the whole riverbank, and distant villages, until the low and crowded houses looked as crimson as hot iron.)

(30) Yuèguāng xiàng bàn zhāng xīzhǐ biăo zài kàng shang. (月光像半张锡纸裱在炕上。(梁晓声(喋

血》) / Moonlight looked like half a tinfoil pasted on the bed.)

In the traditional simile in (29) and (30), "crimson" is a possible feature for both the substance word "houses" and the medium word "iron", so it is an expressive figure of comparison; but "pasted on the bed" is only a possible feature of medium word "tinfoil", but an impossible feature of the substance word "moonlight". So the latter is a cognitive figure.

(31) Tiān rède fāle kuáng. (天热得发了狂。(老舍《骆驼祥子》)/ It is hot as mad.)

(32) Wǒ fēi shuì tā gè bā tiān bā yè bùkě. (我非睡它个八天八夜不可。/ I have to sleep for eight days and nights.)

In the traditional hyperbole, the two examples are the same, but they are different phenomena. Any use of cognitive figures is exaggerating to some extent. (31) is cognitive, whereas (32) expressive.

Metonymy is a case of closeness and comprising, and borrowed metaphor (Jieyu, 借喻) is a case of analogy. But it is hard to judge from the meaning whether they are expressive or cognitive; it depends on the purpose of using them. Examples like "huābái húzi biàn qǔxiāole zijīde huà. (花白胡子便取消了自己的话 / The grey beard ate his word) | yǒu ‘qīngdăo' bù hē ‘běijīng'. (有“青岛”不喝‘北京” / drink ‘Tsingdao’ rather than 'Beijing’) | 'dà tuánjié' fāhuīle yòurénde mèilì. (“大团结”发挥了诱人的魅力” / 'Great Unity' displayed its attraction)" are just witty expressions, whose function is like attributive with “de (的)", as in “zhăngzhe huābái húzi de (nàge rén) (长着花白胡子的(那个人) / the man with grey beard), “qīngdăo pái de (píjiǔ) (青岛牌的(啤酒) / Tsingdao-brand beer)”. We must reduce these expressions to find the replaced objects and see whether the figures are successful. In examples (23) and (24), the interlocutors does not expect the interlocutees to find the lost substance words, but try to change their cognitive habit by treating the medium words as substance words. The change of cognitive relationship means that the latter is identified with the former.

\section{Two types of figures and two approaches}

Both cognitive and expressive figures are language facts, but their academic value is different. Expressive figures do not touch the cognitive and deep thinking; they are only expressive skills outside the semantic content-a language processing form for decorative or non-substance vividness. The fashionable saying is, the same notion may be realized with different forms, which show their respective characteristics and effects. In the same 


\section{Liu Dawei $\quad$ Wang Zhiguang}

way, negative rhetoric and positive rhetoric are mentioned. The duty of negative rhetoric is to keep for example a house safe and comfortable; but positive rhetoric means to decorate the house in different fashions - colors, tiling, patterns: that is the duty of figures of speech. This habit of dividing language expression into a substance and a decoration and then being satisfied with the decoration part has reduced traditional rhetoric to trivial skills forever outside the academic temple. Against the background of modern thinking, the simple notion of decoration has been replaced by the integrated notion of function as form and the integration of substance and external form. The most typical example is architecture. The substance of buildings is function, and forms not functioning are meaningless, no matter how colorful they are. You can imagine the vitality and academic value of a discipline if it bases all its value on trivial skills.

But the notion behind cognitive figures is totally different. It entails alternatives to the usual cognitive forms, causing shifts of cognitive experience. Usual language forms fit the usual cognitive forms; if cognitive experience is greatly changed and the original language forms no longer fit, language shifts as represented by cognitive figures do appear. These figures of speech are not casual decorations, but the unity of shifts of both cognitive relationship and language forms. More importantly, usual cognitive forms cannot lead to creative thinking, but cognitive creative factors are realized directly and primitively in the language change of cognitive figures. The ability to use this type of figures is a major component of language competence and every native speaker may use a wonderful simile thoughtlessly, especially a child. Hence the earliest release of man's creative instinct should be the use of cognitive figures of speech. In scientific research and literary and artistic creation, creative thinking grows directly from the use of cognitive figures or similar cognitive activities. Recently, the study of metaphor in other disciplines, such as philosophy, psychology, literary and art criticism, is focused on this point. The thesis of human thinking as metaphor is not a summary of all facets of thinking, but a central expression of the creative factors. Reversely, the ability to use cognitive figures is the inducer of creativity. Focus on students' use of cognitive figures means paying attention to their creative potential.

But there is no clear-cut demarcation between cognitive and expressive figures and the former may be used as the latter. Lack of a strong sense of cognitive figures will led to the traditional approach even faced with a case of cognitive figure.

Cognitive figures, once stabilized, will be naturalized into expressive ones. As a realization of creativity, a cognitive figure should be disposable, for creation occurs only once. If we use a cognitive figure in a context for a certain purpose, and form a clause to reflect our shift of cognitive experience, and then reuse the same clause in another context for another purpose, it is probable that the original intense fresh experience will not recur, 
so that the figure becomes an ordinary expressive one. For instance, when someone first called the supports of a table “zhuōtuǐ (桌腿 / legs)", or high-pitched sound “jiān (尖 / shrill) ", it is easy to imagine the new experience of recasting a commonplace table as an animal or visualizing an acoustic phenomenon, thus revolutionizing the deep-rooted cognitive habit. But dominant in daily life are those habitual cognitive forms, and the mutation of cognitive relations and special experience are derived from the intense impact of new collocations. When we wake from the impact of that instantaneous freshness and review the set phrases, the inoculated passionless cognizance is strong enough to resist that spent impact. These set phrases can no longer touch our deep consciousness aside from bringing some vividness, though they are the result of cognitive figures. Thus, we actually use such clauses as "huòbì chíxù píruăn (货币持续疲软 / The currency remains weak.)", “yàzhōu huòbì huànshàng ruăngǔbìng (亚洲货币患上软骨病 / Asian currencies suffers from osteomalacia.)" as expressive figures. If they are used as frequently in the future, their meaning will become a constant factor. Then their use will not cause cognitive shifts or even the proper effect of expressive figures: will we associate table legs with animal limbs, unless we study its etymology and assume ourselves in primitive condition?

In more cases, cognitive figures are arbitrarily comprehended as expressive ones, to which the traditional rhetoric is confined. But in practice, especially in literary language, a lot of wonderful examples are cognitive figures, which are nevertheless distorted in teaching and research as expressive ones. Here we called it rhetoric reduction. While the interlocutee felt in his credulous passion a possible world, where "yè hé shīmíngde yěténg hái zài nàli mōsuǒzhe bēi shàng de zìì. (夜和|失明的野藤|还在那里摸索着|碑上的字迹 / The night and blind vines were groping for inscription on the tablet)", or saw in good faith “yì zhī zhī píjuànde shǒu zhōng shēngqū dīchénde wūyún (一只只疲倦的手中|升起低沉的 乌云 / From weary hands rose low dark cloud.)" and appreciated the poetry in the clause, the traditional rhetoric said in a cool, mediocre voice that this was personification of "night" and "vines", which otherwise could not grope; whereas "low dark cloud" was a metaphor, for cigarette smoke.... The traditional rhetoric only reduces perceptive logic to common logic. After that, the possible world of poetry is shattered. Indeed, if simile is only "an expression which describes a person or thing as being similar to someone or something else", metonymy is only "word replacement" or "substitution of a word referring to an attribute for the thing that is meant"..., and we do not explore the cognitive shift behind this, then even the most wonderful figures will be distorted into a mediocre operation.

\section{Conclusion}

There is only relative distinction between expressive and cognitive figures of speech. Remaining on the surface level of expressive effect, all figures are expressive. The 


\section{Liu Dawei $\quad$ Wang Zhiguang}

cognitive figures discussed here are considered as expressive in the traditional rhetoric. Yet the expressive effect can be attributed to some cause, which provides us with a deeper explicative level to comprehend this effect and the language forms that bring it. In this way we have generalized the cognitive figures, which attract our attention with their special expressive effect. But we are not happy with the effect itself, and find that the effect is caused by cognitive shifts. By semantic analysis we conclude that cognitive shifts result in semantic features that come from the acceptance of impossible features. So we have a unified theory and methodology to study the system of such figures.

Hence, expressive and cognitive figures are concepts on different cognitive levels. The former is produced through common sense as surface phenomena not yet treated by linguistic theory, for which traditional rhetoric is meant. Further research on figures may follow the approach to cognitive figures: looking for the cause of expressive effect behind the expressive figures and linguistic theory applicable to it. So we can form deep figures of speech with a theoretical viability which are parallel to cognitive figures. Once the expressive figures are all thus resolved, we will have an integrated system of figures. Of course, we need to find a common dominating factor for various explanatory causes and, above all, a unified linguistic methodology.

\section{References}

Arieti, S. 1976. Creativity: The Magic Synthesis. [M] New York: Basic Books.

Best. J.B. 1998. Cognitive Psychology. [M] Boston: Heinle and Heinle Publishers, A Division of International Thomson Publishing Inc.

Hu Fanzhu. 1998. Problems of $20^{\text {th }}$ Century Chinese Rhetoric Studies. [J] Fudan Journal. No.6.

Liu Dawei. 1989. A Study of Exceptional Sentences. [J] Journal of East China Normal University. No.2. 